\title{
Acritarchs of the Ediacaran Frecheirinha Formation, Ubajara Group, Northeastern Brazil
}

\author{
LETICIA CHIGLINO ${ }^{1,3}$, CLAUDIO GAUCHER ${ }^{2}$, \\ ALCIDES N. SIAL ${ }^{3}$ and VALDEREZ P. FERREIRA ${ }^{3}$ \\ ${ }^{1}$ PDU Geología y Recursos Minerales, CURE, Universidad de la República, \\ Simón del Pino 1132, 33000 Treinta y Tres, Uruguay \\ ${ }^{2}$ Departamento de Geología, Facultad de Ciencias, Universidad de la República, \\ Iguá 4225, 11400 Montevideo, Uruguay \\ ${ }^{3}$ NEG-LABISE, Departamento de Geologia, Universidade Federal de Pernambuco, \\ Av. Acadêmico Hélio Ramos, s/n, 50740-530 Recife, Brasil
}

Manuscript received on August 29, 2014; accepted for publication on January 19, 2015

\begin{abstract}
We report for the first time the occurrence of organic-walled microfossils in Ediacaran limestones and marls of the Frecheirinha Formation, Ubajara Group, and the first Precambrian acritarchs so far reported for northeastern Brazil. The assemblage of the Frecheirinha Formation represents a low-diversity microflora comprising Leiosphaeridia, Lophosphaeridium and subordinated Bavlinella (=Sphaerocongregus). Their thermal alteration index (TAI) between $4+$ and 5, suggests metamorphic temperatures exceeding $200-250^{\circ} \mathrm{C}$. Higher temperatures are probably related to intruding granitic plutons (Meruoca, Mucambo). Reported $\delta^{13} \mathrm{C}$ values of carbonates of $-3.5 \%$ VPDB (Vienna-Peedee Belemnite) at the base, passing up section into a positive plateau of up to $+3.7 \%$, and corresponding ${ }^{87} \mathrm{Sr} /{ }^{86} \mathrm{Sr}$ values between 0.7075 and 0.7080 suggest an Ediacaran age. The acritarch assemblage is comparable to the Late Ediacaran Leiosphere Palynoflora (LELP) or Kotlin-Rovno assemblage, in broad agreement with chemostratigraphic data. Macrofossils belonging to the Ediacara fauna were reported from the overlying Jaibaras Group, which would constrain even further the depositional age of the Frecheirinha Formation to within ca. 575-555 Ma. A more comprehensive palynological study of the Frecheirinha Formation is necessary to confirm this age assignment.
\end{abstract}

Key words: Acritarchs, Ediacaran, Neoproterozoic, northeastern Brazil.

\section{INTRODUCTION}

The Neoproterozoic is characterized by extreme climate change, oscillations in oceanic geochemistry, a significant oxygenation event, and the diversification of the marine biota (Hoffman and Schrag 2002, Willman et al. 2006, Frei et al. 2009,

Correspondence to: Leticia Chiglino

E-mail: leticia@ufpe.br
Halverson et al. 2010). Several near-global glacial events ocurred between 740 and $580 \mathrm{Ma}$, considered as a bottleneck for marine biota evolution (Kaufman and Knoll 1995, Moczydłowska 2008).

Neoproterozoic body fossils have been described for a few successions in Brazil, the most diverse being the assemblage preserved in the late Ediacaran Corumbá Group, Mato Grosso do Sul (e.g. Beurlen 
and Sommer 1957, Zaine and Fairchild 1985, Gaucher et al. 2003, Fairchild et al. 2012 Warren et al. 2012).

Until recently, no Neoproterozoic body fossils were known from northeastern Brazil. Soft-bodied macrofossils typical of the Ediacara Fauna, which can be assigned to the White Sea assemblage (Narbonne 2005), were recently described from the Jaibaras Group, Ceará (Barroso et al. 2014, Figs. 1-2). The Jaibaras Group overlies the Ubajara Group (Fig. 2), which comprises thick carbonates rocks of the Frecheirinha Formation, with an erosional unconformity between the two groups. The Ubajara Group represents a proximal platform sequence, composed, from base to top, of the following formations (Fig. 2a): (a) Trapiá (quartz conglomerate), (b) Caiçara (ferruginous siltstones),

(c) Frecheirinha (limestones and subordinate marls) and (d) Coreaú (sandstone and greywacke) located in the Médio Coreaú Domain, Borborema Province. This Domain is characterized by graben and horst structures controlled by NE-trending shear zones, and is bounded to the northeast by the Transbrasiliano Lineament, which separates it from the Ceará Central Domain (Caby et al. 1991, Santos et al. 2008). The age of the carbonate rocks of the Frecheirinha Formation is poorly constrained by $\mathrm{C}-$ and $\mathrm{Sr}$-chemostratigraphy and radiometric ages as late Neoproterozoic (Sial et al. 2000, 2003, Chiglino 2013).

In the present work, we describe organic-walled microfossils (acritarchs) from the Frecheirinha Formation, which contribute towards our understanding of the depositional environments, age and thermal overprint of the Ubajara Group. These are the first Precambrian acritarchs reported, so far, from northeastern Brazil.

\section{LITHOSTRATIGRAPHY AND AGE}

The Ubajara Group represents a proximal platform sequence (Costa et al. 1979, Hackspacher et al. 1988), the type area is located along the road BR 222 between Aprazível and Saco towns, roughly $300 \mathrm{~km}$ from the city of Fortaleza (state of Ceará; Fig. 1). This sedimentary succession reaches $3000 \mathrm{~m}$ in thickness and is composed, from base to top, by:

(a) Trapiá Formation sandstones.

(b) Caiçaras Formation, fine-grained sandstones which pass into red, finely laminated siltstones up section.

(c) Frecheirinha Formation, pink and dark gray limestones and subordinated marls at the base and gray limestones with microbial lamination at the top.

(d) Coreaú Formation, sandstones and graywackes.

The contact between the base of the Ubajara Group and the basement is not exposed, and at the top it is overlain by the Jaibaras Group with erosional unconformity (Oliveira 2000, Santos et al. 2008).

The Frecheirinha Formation is a carbonate unit about $500 \mathrm{~m}$ in thickness, the type area is located near the Frecheirinha town and the best exposures are observed at the quarry of the Companhia Cearense de Cemento Portland (CCCP), north of Aprazível. The strata exhibit intense ductile deformation recorded by folds with axes oriented NE-SW and, locally, low grade metamorphism.

Carbonates are characterized by limestones and marly rythmites in the lower part, which pass into dark gray to gray, fine, laminated, stromatolitic limestones at the top. In the Araticum area (Fig. 1), carbonates are composed of fine-grained, calcitic mudstones (grain size: $10 \mu \mathrm{m}$; Figs. 3a-b) intercalated with organic-rich marls (Fig. 3a), in which microfossils are preserved. On the other hand, in the Angustura farm region recrystallization of carbonates is evident, and the occurrence of tremolite in the limestones (Figs. 3c-d) indicates that they reached low-grade metamorphic conditions. This metamorphism was probably caused by the nearby Mucambo Granite (Fig. 1) and is not regional in nature.

The Araticum profile, located between the Frecheirinha and the Ubajara village (Fig.1), was 


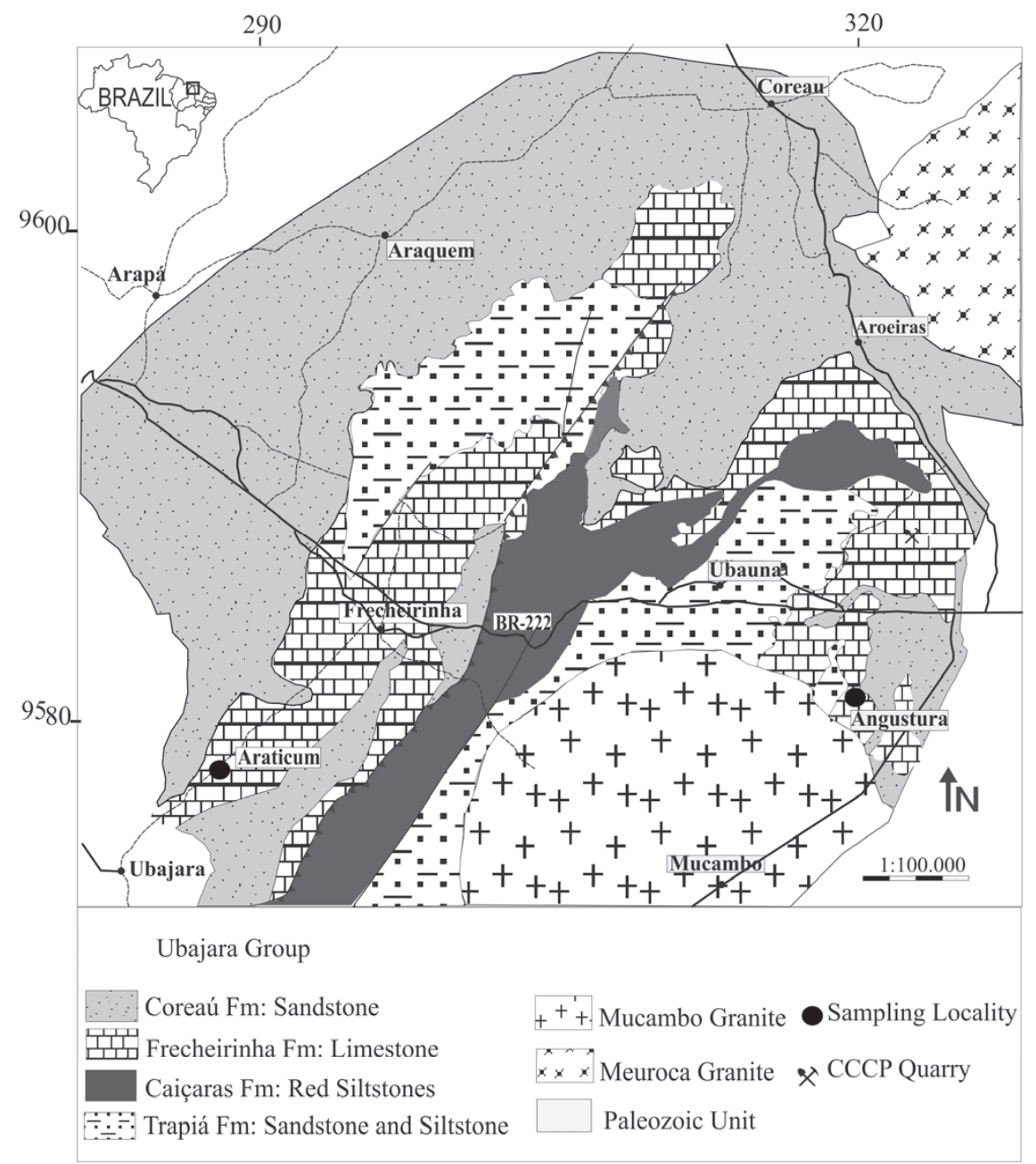

Fig. 1 - Geological map of the studied area, showing the Ubajara Group and sampled outcrops of the Frecheirinha Formation (Araticum Section).

selected for the palynological study because of the lower thermal overprint. There, limestone-marl rhythmites occur at the base, which grade into dark gray to black, finely laminated, organic-rich limestones at the top (Fig. 2).

Barroso et al. (2014) reported the occurrence of probable soft-bodied Ediacaran macrofossils in the overlying Jaibaras Group, similar to the White Sea assemblage, which justify an Ediacaran age for this unit (560-542 Ma: Narbonne 2005, Fedonkin et al. 2007). These biostratigraphic relationships may provide a minimum late Ediacaran age constraint for the
Frecheirinha Formation, but it needs a more detailed study to explore the paleontological affinity of the macrofossils described by Barroso et al. (2014) and their relationship to the Ediacara fauna.

The age of the Ubajara Group is still uncertain due to the lack of reliable radiometric ages. The minimum age is constrained by the following ages:

(a) a $\mathrm{Rb}-\mathrm{Sr}$ age of $562 \pm 19 \mathrm{Ma}$ determined for the Coreaú dike swarm, which crosscuts the sequence (Sial and Long 1987),

(b) the Mucambo Granite intrudes the Ubajara Group (Fig. 1) and yielded a U-Pb crystallization age of $532 \pm 7 \mathrm{Ma}$ (Santos et al. 2008), and 


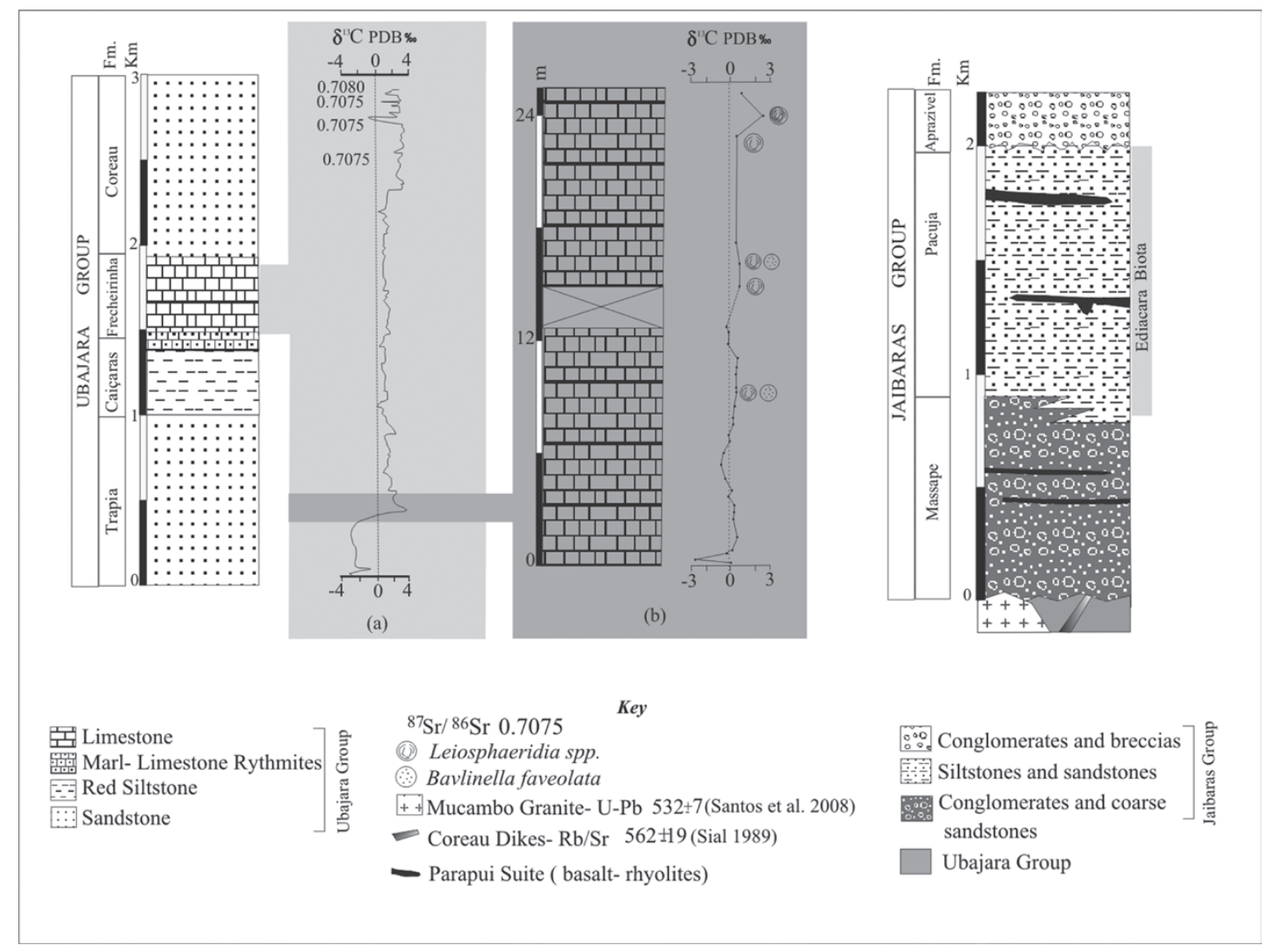

Fig. 2 - Lithostratigraphy of the Ubajara and Jaibaras groups, showing stratigraphic range of fossils occurring in these units. a-Chemostratigraphy $\left({ }^{13} \mathrm{C}\right.$ and ${ }^{87} \mathrm{Sr} /{ }^{86} \mathrm{Sr}$ ) of the entire Frecheirinha Formation (Sial et al. 2003, Chiglino 2013). b-Detail of the stratigraphic interval sampled in this work.

(c) a $\mathrm{Rb}-\mathrm{Sr}$ age of $540 \pm 24 \mathrm{Ma}$, a U-Pb age of $532 \pm 24 \mathrm{Ma}$ (Fetter et al. 2003) and a U-Pb SHRIMP age of $541 \pm 5 \mathrm{Ma}$ (Santos et al. 2013) for the Meruoca Granite, which intrudes the group and develops an important contact aureole. The U-Pb SHRIMP age of $541 \mathrm{Ma}$ is considered the best age estimate for the crystallization of the pluton.

Chemostratigraphic data presented by Chiglino (2013, Fig. $2 \mathrm{a}$ and $\mathrm{b}$ ) show negative $\delta^{13} \mathrm{C}$ values of $-3.5 \%$ VPDB at the base, passing up section into a positive excursion with maximum values of $+3.7 \%$. Corresponding ${ }^{87} \mathrm{Sr} /{ }^{86} \mathrm{Sr}$ values range between 0.7075 and 0.7080 (Sial et al. 2003). Especially the Sr isotope ratios, which were obtained from high-Sr limestones (Sr concentration up to 3500 ppm: Chiglino 2013), favor a latest Cryogenian to Ediacaran depositional age (e.g. Jacobsen and Kaufman 1999, Melezhik et al. 2001, Halverson et al. 2007). However, late Cryogenian successions are often characterized by elevated $\delta^{13} \mathrm{C}$ values of up to $+8 \%$ VPDB which drop to negative values before the end-Cryogenian glaciation (Halverson et al. 2005). This pattern is not observed in the Frecheirinha Formation. Instead, a plateau around $+3 \%$ VPDB characterizes most of the unit and post-dates a negative excursion, similar to that observed for the late Ediacaran Nama and Corumbá groups (Grotzinger et al. 1995, Boggiani et al. 2010; Table I). Likewise, a negative excursion followed by moderately positive values is also observed in the late Ediacaran upper Polanco Formation (Arroyo del Soldado Group, Uruguay), 
TABLE I

Table showing key correlation features for several Neoproterozoic units dominated by Bavlinella and/or Leiosphaeridia. Features shown include radiochronometric constraints (mainly $\mathrm{U}-\mathrm{Pb}$ ), $\delta^{13} \mathrm{C},{ }^{87} \mathrm{Sr} /{ }^{86} \mathrm{Sr}$ and relative.

Sources of data: 1: Chiglino 2013 and this work. 2: Germs et al. (1986), Grotzinger et al. (1995). 3: Gaucher (2000), Gaucher and Poiré (2009), Gaucher et al. (2009), Blanco et al. (2009). 4: Gaucher et al. (2003), Boggiani et al. (2010).

5: Mallmann et al. (2007), Gaucher et al. (2008), Oyhantçabal et al. (2009). 6: Grey (2005), Walter et al. (2000), Kendall et al. (2006). 7: Yin and Yuan (2007), Zhang et al. (2008). 8: Germs et al. (2009), Halverson et al. (2005), Hoffman et al. (1996), Hoffmann et al. (2004). 9: Nagy et al. (2009), Karlstrom et al. (2000).

\begin{tabular}{|c|c|c|c|c|c|c|c|}
\hline Unit & $\begin{array}{c}\text { Absolute } \\
\text { ages (Ma) }\end{array}$ & $\begin{array}{c}\delta^{13} \text { Cearb \%o } \\
\text { V-PDB }\end{array}$ & ${ }^{87} \mathrm{Sr} /{ }^{86} \mathrm{Sr}$ & $\begin{array}{c}\text { Thin-walled } \\
\text { Leiosphaeridia }\end{array}$ & $\begin{array}{l}\text { Thick-walled } \\
\text { Leiosphaeridia }\end{array}$ & Bavlinella & Remarks \\
\hline $\begin{array}{l}\text { Frecheirinha } \\
\text { Fm.1 }\end{array}$ & $>560 \mathrm{Ma}$ & -3.5 to +3.7 & $\begin{array}{l}0.7075- \\
0.7080\end{array}$ & Dominant & Present & Subordinate & \\
\hline $\begin{array}{l}\text { Lower Nama } \\
\text { Group2 }\end{array}$ & $549-543$ & -4 to +5 & 0.7085 & Dominant & Common & Subordinate & Cloudina \\
\hline $\begin{array}{l}\text { Lower Arroyo } \\
\text { del Soldado } \\
\text { Group3 }\end{array}$ & $<566,>532$ & -4.5 to +5.5 & $\begin{array}{c}0.7070- \\
0.7085\end{array}$ & $\begin{array}{l}\text { Dominant to } \\
\text { common }\end{array}$ & 0 & $\begin{array}{l}\text { Dominant to } \\
\text { common }\end{array}$ & Cloudina \\
\hline $\begin{array}{l}\text { Corumbá } \\
\text { Group4 }\end{array}$ & $>543$ & -4.5 to +5.5 & $\begin{array}{c}0.7084- \\
0.7086\end{array}$ & Subordinate & 0 & Dominant & Cloudina \\
\hline $\begin{array}{l}\text { Las Ventanas } \\
\text { Formation } 5\end{array}$ & $590-573$ & ------- & -------- & Dominant & 0 & 0 & \\
\hline $\begin{array}{l}\text { Lower } \\
\text { Pertatataka } \\
\text { Formation6 }\end{array}$ & $<657 \mathrm{Ma}$ & -3 to +2.5 & $\begin{array}{c}0.7075- \\
0.7080\end{array}$ & Common & Dominant & 0 & \\
\hline $\begin{array}{l}\text { Datangpo } \\
\text { Formation } 7\end{array}$ & $663-654$ & -------- & -------- & Subordinate & Common & Dominant & \\
\hline $\begin{array}{l}\text { Auros Fm., } \\
\text { Otavi Group8 }\end{array}$ & $746-636$ & -6 to +8 & 0.7072 & Present & 0 & Dominant & \\
\hline $\begin{array}{l}\text { Upper Chuar } \\
\text { Group9 }\end{array}$ & $>742$ & -------- & -------- & Common & Present & Dominant & $\begin{array}{c}\text { Valeria } \\
\text { lophostriata, } \\
\text { Cerebrosphaera } \\
\text { buickii }\end{array}$ \\
\hline
\end{tabular}

which is also associated to ${ }^{87} \mathrm{Sr} /{ }^{86} \mathrm{Sr}$ values between 0.7070 and 0.7082 (Gaucher et al. 2009, Frei et al. 2011). Thus, the chemostratigraphic data suggest an Ediacaran age as the most probable depositional age of the Frecheirinha Formation, but so far do not allow a more refined geochronology.

\section{MATERIALS AND METHODS}

Palynological macerations of carbonates were prepared at the Micropaleontology Laboratory of the Departamento de Geología, Facultad de Ciencias (Montevideo). The method does not use centrifugation or ultrasonic bath to avoid breakage of fragile specimens (e.g. Gaucher et al. 2008). Following crushing and digestion of samples with concentrated $\mathrm{HCl}, 72 \% \mathrm{HF}$ was applied for $24 \mathrm{~h}$. After neutralization, boiling $\mathrm{HCl}$ was applied to remove fluorides formed in the previous step. The remaining solution was diluted with water and the supernatant discarded after allowing at least $30 \mathrm{~min}$ for particle settling. The organic residues were recovered by means of a $5 \mu \mathrm{m}$ sieve, stored in glass flasks and mounted with glycerin-gelatine on standard glass slides. Microfossils were determined under a Leica DM LP polarizing microscope, using both transmitted and reflected light (Pflug and Reitz 1992). 
Twelve samples of carbonates and marls of the Frecheirinha Formation at the Araticum section were analyzed. Acritarch preservation was quite poor, mainly due to advanced carbonization, corrosion and fragmentation. Despite the advanced thermal alteration of acritarchs, they could still be classified using reflected light techniques described by Pflug and Reitz (1992).

\section{RESULTS}

Preservation AND Thermal ALteration

Although entire, fairly well-preserved specimens are common, most of the organic remains are fragmentary and/or corroded to some degree. Moreover, acritarchs exhibit advanced carbonization, showing colors from dark gray to black (Figs. 4-6). Corresponding Thermal Alteration Index (TAI) ranges from $4+$ to 5 , suggesting metamorphic temperatures exceeding $200-250^{\circ} \mathrm{C}$ (Teichmüller et al. 1998). It is not yet clear if this metamorphic overprint is of a regional nature or enhanced by the voluminous granitic intrusions affecting the succesion, such as the Meruoca and Mucambo granites (Fig. 1). As we have shown in Figs. $3 \mathrm{c}-\mathrm{d}$, contact metamorphism is evident in the Angustrura section near the Mucambo Granite (Fig. 1), but it is uncertain as to how far away from the pluton's edge this thermal overprint reaches.

Although the advanced carbonization of acritarchs hinders, to some extent, their identification, the use of reflected light techniques allows overcoming this dificculties. Thus, the low diversity observed in the Frecheirinha microflora is considered as a primary feature, and not the result of a taphonomic bias.

\section{Systematic PALAEONTOLOGY}

Repository. All palynological slides, containing specimens described here, are kept in the Precambrian collection of the Departamento de Paleontología, Facultad de Ciencias (Montevideo,
Uruguay). The position of specimens on the slides are clearly marked on corresponding duplicates.

Incertae sedis

Group Acritarcha Evitt (1963)

Genus Leiosphaeridia Eisenack (1958), emend. Downie and Sarjeant (1963), emend. Turner (1984).

Type species: Leiosphaeridia baltica Eisenack (1958)

Leiosphaeridia tenuissima Eisenack (1958)

Figs. 4 a-c

1958 Leiosphaeridia tenuissima Eisenack: pl. 1.2-1.3 1994 Leiosphaeridia tenuissima Butterfield et al.: fig. 16I

1996 Leiosphaeridia tenuissima Hofmann and Jackson: figs. 12E

1998 Leiosphaeridia tenuissima Gaucher et al.: fig. 4.6 2000 Leiosphaeridia tenuissima Gaucher: pl. 11.5 2004b Leiosphaeridia tenuissima Gaucher et al.: fig. 4D

2005a Leiosphaeridia tenuissima Gaucher et al.: fig. $8 \mathrm{~g}-\mathrm{h}$

2006 Leiosphaeridia tenuissima Gaucher and Germs: figs. $7 \mathrm{~d}$, f-g; 8 b-f

2008 Leiosphaeridia tenuissima Gaucher et al.: figs. 3B-I

Material. Slides Arat 29A-1, Arat 29E-7 and Arat 29E-9. Ten fairly well-preserved specimens and fragments in macerations of carbonates, Frecheirinha Formation.

Description. Thin-walled, psilate, originally spheroidal vesicles with common folds. Diameter ranging between 70 and $100 \mu \mathrm{m}$ (mean=84 $\mu \mathrm{m}$; $\mathrm{N}=5$ ). Two different patterns of folding of the walls were observed in the vesicles: (a) simple, psilate sphaeromorphs with mainly concentric folds (Fig. 4.a); and (b) vesicles with a microplicate wall (Figs. 4.b, c).

Remarks. L. tenuissima is the most frequent species in the black limestones of the Araticum section, and represents the base of the Frecherinha Formation. Two different wall structures are included here under L. tenuissima: one with a thin, 

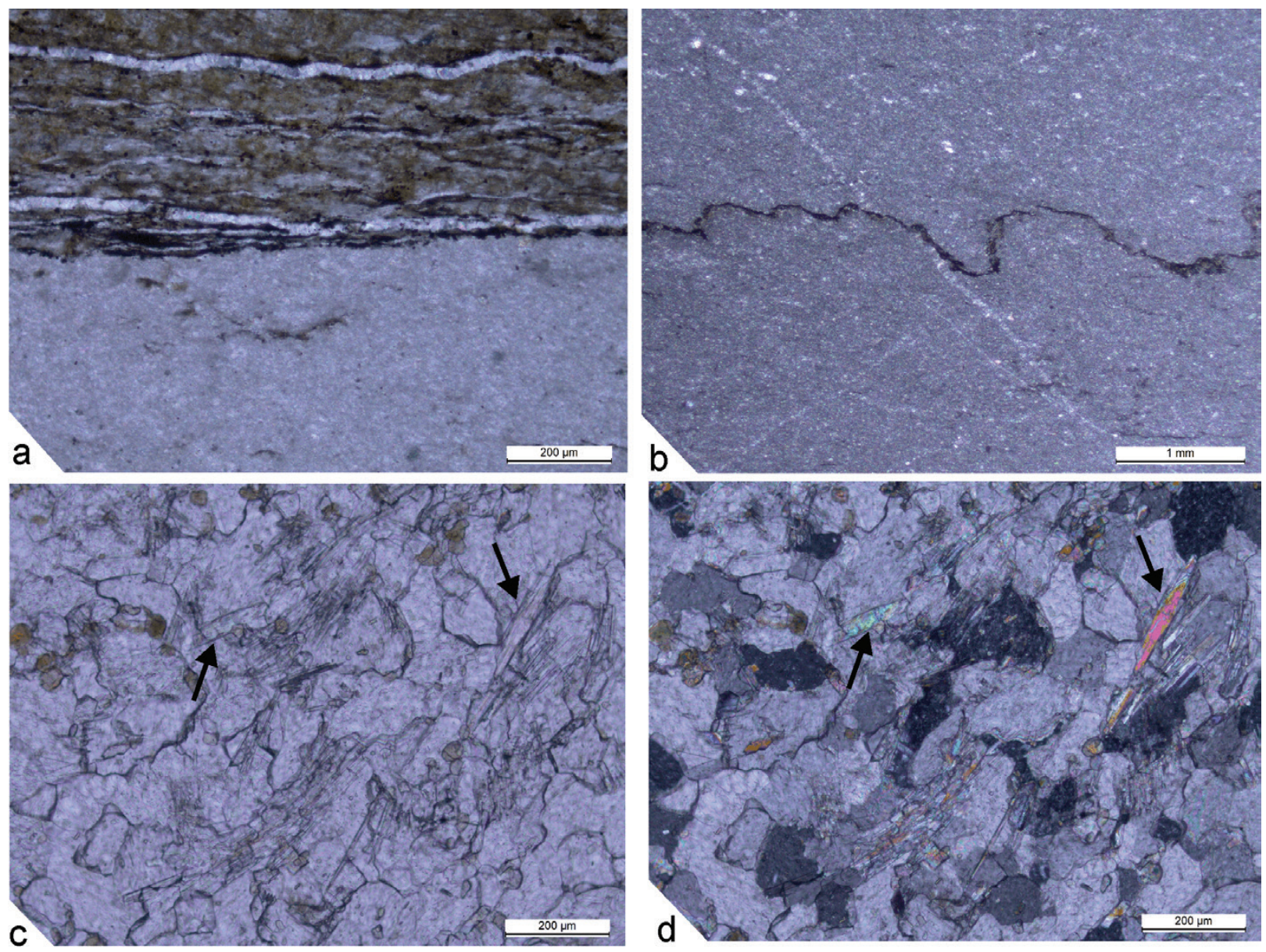

Fig. 3 - Microphotographs of thin sections of carbonates of the Frecheirinha Formation. a-Contact between calcitic mudstone (below) and organic-rich marl, Araticum section, crossed nicols. b-Stylolite in fine-grained limestone (Araticum section), planepolarized light. c-Recrystallized limestone (marble) from the Angustura section, plane-polarized light. Note tremolite crystals. d-Same as previous, crossed nicols.

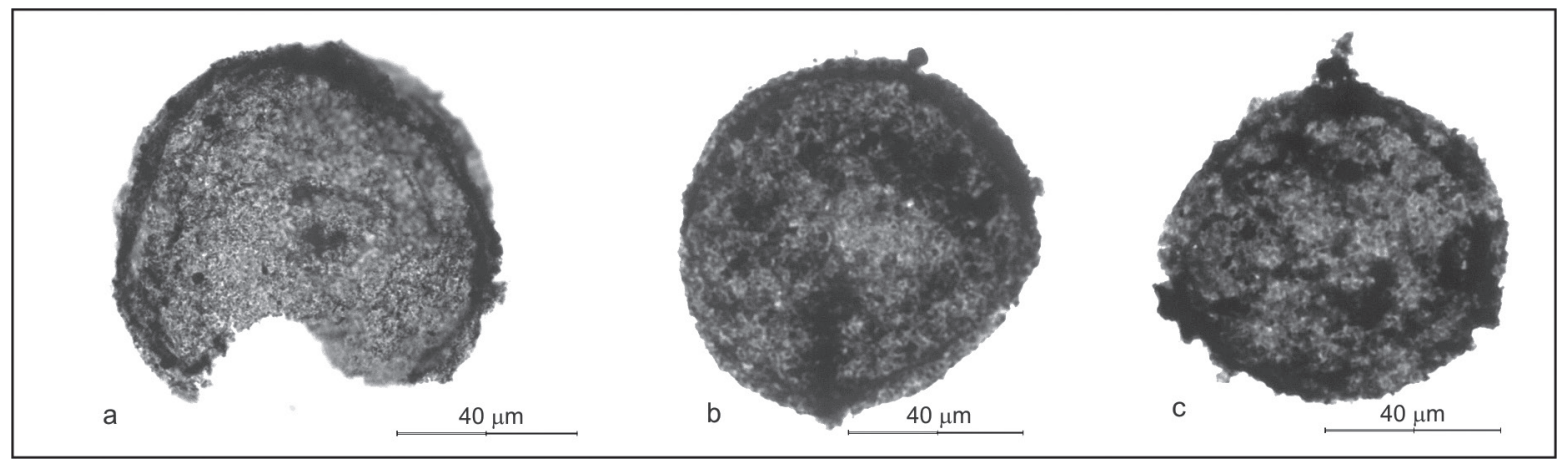

Fig. 4 - Sphaeromorphs of the Frecheirinha Formation recovered from limestones (Araticum Section) by means of standard palynological maceration. a- Leiosphaeridia tenuissima Eisenack (1958), specimen Arat 29A-1, b-L. tenuissima Eisenack (1958), specimen Arat 29E-9, c-L. tenuissima Eisenack (1958), specimen Arat 29E-7. 


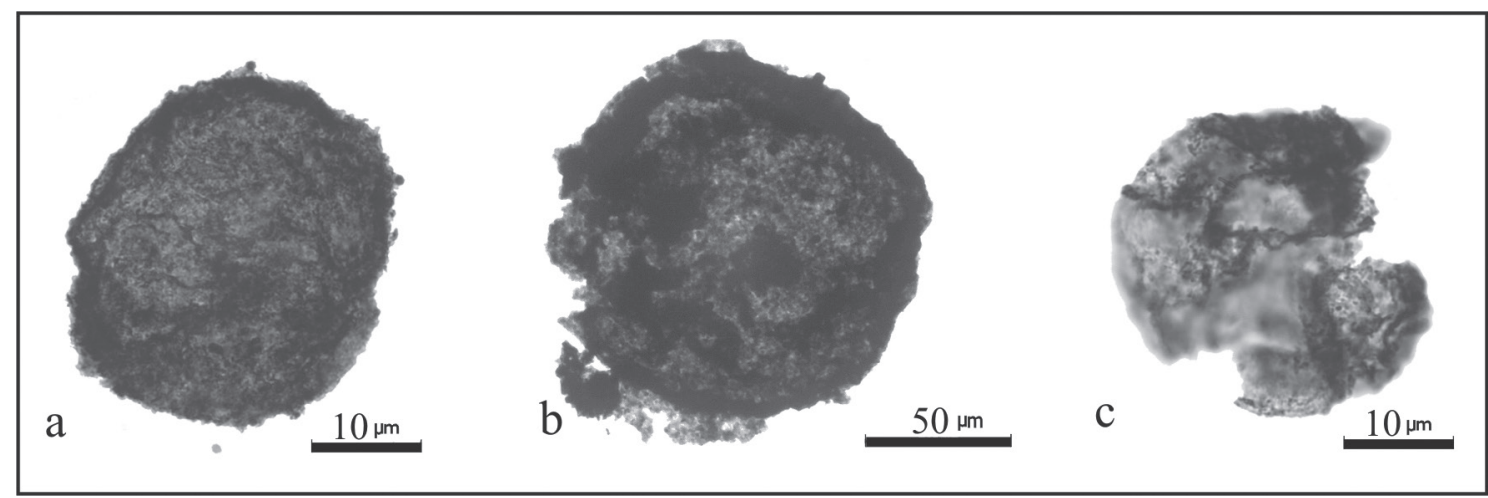

Fig. 5 - a- Leiosphaeridia minutissima Naumova (1949), specimen Arat 29A-5, b- Leiosphaeridia jacutica (Timofeev 1966), specimen ARAT 29E-8, c- Lophosphaeridium sp, specimen 110227/2B-2.
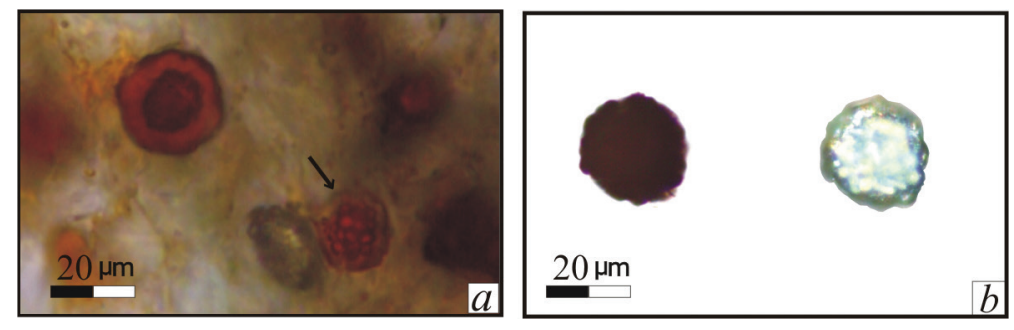

Fig. 6 - a-Thin section of limestone (Araticum section) showing hematized Bavlinella faveolata (Schepeleva) Vidal (1976), specimen ARAT 30 (arrowed), b-Bavlinella faveolata from a palynological maceration of black limestone, specimen ARAT 29C-8 in transmitted light (left) and in combined reflectedtransmitted light (right), showing individual microspheres.

but still competent wall, the other with a very thin, pliable membrane. The same wall structure has been observed in specimens from other Ediacaran units in South America: Las Ventanas Formation of Uruguay (Gaucher et al. 2008), and the Sierras Bayas Group of Argentina (Gaucher et al. 2005b).

Leiosphaeridia minutissima Naumova (1949), emend. Jankauskas et al. (1989)

Fig. 5a

1992 Leiosphaeridia minutissima Butterfield and Chandler: figs. 3A-3I

1996 Leiosphaeridia minutissima Hofmann and Jackson: figs. 15.9-15.15, 15.16

1996 Leiosphaeridia minutissima Hofmann and Jackson: figs. 12A-C 2000 Leiosphaeridia minutissima Gaucher: p. 66
2008 Leiosphaeridia minutissima Gaucher et al.: fig. $3 \mathrm{~A}$

Material. Slides ARAT 20B, 29A-5, 29B, 34A and $35 \mathrm{~A}$, few specimens and vesicle-fragments in palynological macerations of carbonates, Frecheirinha Formation.

Description. Thin-walled and psilate, originally spheroidal vesicles with common, irregular to concentric folds. Diameter ranging from 40 to 70 $\mu \mathrm{m}$ (mean $=57 \mu \mathrm{m} ; \mathrm{N}=3$; Fig. 4.a).

Remarks. The specimens show irregular folds on the wall which appear as darker patches and soft waves. Here we applied the criteria established by Jankauskas et al. (1989) for the classification of leiospherids. This taxon occurs as a subordinate component of the microbiota of Frecheirinha Formation. 
Leiosphaeridia jacutica (Timofeev 1966) emend. Mikhaylova and Yankauskas in Jankauskas et al. 1989

Fig. $5 \mathrm{~b}$

1989 Leiosphaeridia jacutica Mikhaylova and Jankauskas (in Jankauskas et al. 1989): fig 3a,b,7,9 1994 Leiosphaeridia jacutica Butterfield et al.: fig. 16H

Material. Fourcarbonized specimens in palynological macerations, Araticum Section (sample ARAT 29).

Description. Several thick-walled, spheroidal vesicles, characteized by a rough surface, concentric folds and diameter roughly between 100 and 200 $\mu \mathrm{m}$. Most specimens are opaque in transmitted light, and only a few are translucent (Fig. 5b).

Remarks. The thicker walls compared to $L$. tenuissima cause the opaqueness of the vesicles. The species is a common constituent of Neoproterozoic microbiotas worldwide.

Genus Lophosphaeridium Timofeev (1959), ex

Downie (1963), emend. Lister (1970)

\section{Lophosphaeridium sp.}

Fig. 5c

Material. Poorly preserved and few specimens in palynological maceration 110227/2B-2 of carbonates in the Araticum Section.

Description. Robust-walled vesicles with verrucate, plicated surface. Verrucae are less than $1 \mu \mathrm{m}$ in diameter. Folds are prominent and the diameter of the only complete specimen observed is $46 \mu \mathrm{m}$. (Fig. 5.c)

Remarks. These sphaeromorphs are left in open nomenclature because of the small number of specimens observed and due to their poor preservation. Although we cannot totally rule out that these are degraded (corroded) Leiosphaeridia specimens, the regularity of the verrucae suggests that they are original structures and not taphonomic artifacts. The microfossils described under this taxon are similar to those reported by Gaucher et al. (2008) under Lophosphaeridium sp. for the Las Ventanas Formation (Uruguay).
Kingdom Eubacteria Woese and Fox (1977)

Phyllum Cyanobacteria Stanier et al. (1978)

Classis, Ordo et Fam. indet.

Genus Bavlinella (Schepeleva) Vidal (1976)

Type species. Bavlinella faveolata (Schepeleva)

Vidal (1976)

Bavlinella faveolata (Schepeleva) Vidal (1976)

Fig. 6

1974 Sphaerocongregus variabilis Moorman: pls. 1-3 1976 Bavlinella faveolata Vidal : figs. 7A-C

1992 Bavlinella faveolata Schopf : pl. 54-J

2000 Bavlinella faveolata Gaucher: pl. 9, pl. 18.1-18.2 2003 Bavlinella faveolata Gaucher et al.: figs. 5C$\mathrm{H}, 6 \mathrm{~F}$

2005a Bavlinella faveolata Gaucher et al.: figs. 6a-i 2006 Bavlinella faveolata Gaucher and Germs: figs. 6a-o, 7a-c

2009 Sphaerocongregus variabilis Nagy et al., figs. $1 \mathrm{~m}-\mathrm{n}$

Type specimen. German et al. (1989) designated a lectotype for the species from the Kotlin Formation of the former USSR. This lectotype has also been illustrated by Schopf (1992: pl. 54-J). Therefore, the valid designation of a lectotype supersedes any previous restriction of the application of the name of the genus and species Bavlinella faveolata. Sphaerocongregus variabilis Moorman (1974) is thus to be considered as a junior synonym (Vidal 1976, Gaucher et al. 2003).

Material. Seven specimens occur both in thin section ARAT 30 and palynological macerations (ARAT 20, 29C and 35B) of carbonates from the Frecheirinha Formation

Description. The observed specimens were mainly single spheroidal vesicles made up of tens of tightlypacked, micron-sized (1-2 $\mu \mathrm{m})$ microspheres (Fig. 6.a), thus corresponding to the endosporangia morphotype of Moorman (1974). Two types of preservation were observed: carbonized remains, 
mainly occurring in macerations, and hematized specimens (only in thin sections). Both types of preservation are common for the species (e.g. Gaucher 2000, Gaucher et al. 2003, Gaucher and Germs 2006). Diameter of vesicles ranges between 5 and $20 \mu \mathrm{m}$ (mean=12 $\mu \mathrm{m}, \mathrm{N}=17$ ).

Remarks. B. faveolata is a subordinate component in the acritarch assemblage, which is clearly dominated by leiosphaerids. However, a few organic-rich marl layers preserve mass occurrences of $B$. faveolata, which is a common feature of the species (Moorman 1974, Gaucher and Germs 2006, Nagy et al. 2009).

\section{DISCUSSION}

The low-diversity fossil assemblage of the Frecheirinha Formation comprises Leiosphaeridia, Lophosphaeridium and subordinated Bavlinella faveolata (=Sphaerocongregus variabilis). Both Leiosphaeridia and Bavlinella are long-ranging microfossils, but occur as an assemblage (Table I) in the Cryogenian (e.g. Knoll et al. 1981, Nagy et al. 2009, Yin and Yuan 2007) early and late Ediacaran successions, worldwide (e.g. Germs et al. 1986, Gaucher et al. 2003, 2008, Gaucher and Germs 2006, Grey et al. 2003).

The Cryogenian occurrences are usually characterized by a strong dominance of Bavlinella faveolata in almost monospecific assemblages. Examples in North America are the Mineral Fork Formation from Utah, USA (Knoll et al. 1981) and its correlative Uinta Mountain Group in the same region (Nagy and Porter 2005), and the upper Chuar Group (Nagy et al. 2009). All these units are constrained to the lower Cryogenian, between $770 \mathrm{Ma}$ and $740 \mathrm{Ma}$ (Table I, Nagy et al. 2009, Link and Christie-Blick 2011). Similar, Bavlinelladominated assemblages occur just prior to the endCryogenian glaciation (Table I) in the Otavi Group in Namibia (Germs et al. 2009) and in the Datangpo Formation in South China (Yin and Yuan 2007).
Again in these cases, Bavlinella faveolata strongly dominates the assemblages, unlike the Frecheirinha assemblage, in which Bavlinella is a subordinated component. Furthermore, vase-shaped microfossils (VSM's) and other acritarchs occur in the Cryogenian assemblages (Nagy and Porter 2005, Huntley et al. 2006, Nagy et al. 2009), such as Cerebrosphaera, Valeria and Trachysphaeridium, none of which occur in the Frecheirinha Formation.

The evolution of acritarchs in the Ediacaran (ca. 635-541 Ma) can be divided into three phases (Gaucher and Sprechmann 2009, and references therein):

The Ediacaran Leiosphere Palynoflora (ELP; Grey 2005), re-named as Early Ediacaran Leiosphere Palynoflora (EELP: Gaucher and Sprechmann 2009), which is characterized by Leiosphaeridia-dominated assemblages, typically with large acritarchs $>200 \mu \mathrm{m}$ in diameter, and with abundance of the thick-walled Leiosphaeridia crassa (Grey 2005). Bavlinella faveolata -if present at all- is a subordinated component and acanthomorphs are absent. This assemblage occurs in successions deposited after the end-Cryogenian glacial event (635 Ma), and before the Gaskiers glacial event at ca. $580 \mathrm{Ma}$ (Liu et al. 2013).

The Ediacaran Complex Acanthomorph Palynoflora (ECAP: Grey et al. 2003, Grey 2005), best represented in China and Australia (Zang and Walter 1992), but also known from other sections (e.g. Sergeev et al. 2011, Moczydlowska and Konstantin 2012) is made up of a diverse assemblage of spiny acritarchs (acanthomorphs). It has been recently divided into a lower Tianzhushania spinosa-assemblage, only represented in the lower Doushantuo Formation, and an upper, more widespread Tanarium anozos-Tanarium conoideum assemblage (Liu et al. 2013). The stratigraphic distribution of the ECAP is narrow, possibly representing between 5 and 15 Myr (Grey 2005).

The Late Ediacaran Leiosphere Palynoflora (LELP; Gaucher and Sprechmann 2009) or KotlinRovno assemblage of Vidal and Moczydlowska-Vidal 
(1997), marks a late Ediacaran crisis, represented by a low-diversity assemblage, characterized mainly by thin-walled Leiosphaeridia spp., more or less abundant Bavllinela faveolata, colonial microfossils of the genus Soldadophycus and small acanthomorphs of the genus Asteridium. Soft-bodied and skeletal metazoans co-occur with the depauperate acritarch assemblage. This assemblage spans the period between ca. 575-560 $\mathrm{Ma}$ and the Neoproterozoic-Cambrian boundary at $541 \mathrm{Ma}$ (Gaucher and Sprechmann 2009).

Two Ediacaran acritarch assemblages resemble the Frecheirinha microflora, namely the EELP and LELP. The abundance of thin-walled Leiosphaeridia spp., less abundance of Bavlinella and complete absence of ECAP acanthomorphic acritarchs suggest an assignment of our fossil material to the Late Ediacaran Leiosphere Palynoflora (LELP). On the other hand, there are similarities with the Early Ediacaran Leiosphere Palynoflora (EELP). However, the absence of Leiosphaeridia crassa, the main taxon of the EELP(Grey 2005), and the common occurrence of Bavlinella militate against an assignment of the Frecheirinha microflora to the EELP. The closest counterparts of the Frecheirinha acritarchs are assemblages from (Table I) the Corumbá Group in the southern Paraguay Belt, Brazil (Gaucher et al. 2003), the Arroyo del Soldado Group in Uruguay (Gaucher 2000, Gaucher and Poiré 2009) and the Nama Group in southern Africa (Germs et al. 1986), all of which are younger than $565 \mathrm{Ma}$. They represent impoverished acritarch assemblages dominated by thin-walled Leiosphaeridia with occurrence of Bavlinella faveolata. Furthermore, all the mentioned units share similar $\mathrm{C}$ and $\mathrm{Sr}$ isotope composition of carbonates with the Frecheirinha Formation (Table I).

The apparent absence in the Ubajara Group of clear glacial deposits and sedimentary features typical of post-glacial cap carbonates (Hoffman and Schrag 2002) do not allow us to relate the Frecheirinha Formation to any glacial event, which fits a late Ediacaran age. Sedimentological evidence of such an event is so far lacking. Chemostratigraphic studies of the carbonates (Sial et al. 2003, Chiglino 2013) reported negative $\delta^{13} \mathrm{C}$ values $(-3.5 \%)$ at the base of the unit that may be related to periods of low plankton bioproductivity or sea level fluctuations (Gaucher et al. 2004a, Frei et al. 2011). The dark gray to black, laminated limestones of the Araticum section, start with a negative $\delta^{13} \mathrm{C}$ excursion $(-3 \%)$, followed by positive values up to $+3 \%$ for the rest of the unit, and the samples analyzed in this study come from the interval with positive $\delta^{13} \mathrm{C}$ values.

\section{CONCLUSIONS}

The low-diversity microflora comprising Leiosphaeridia, Lophospheridium and subordinated Bavlinella, found in carbonates of the Frecheirinha Formation, is here assigned to the Late Ediacaran Leiosphere Palynoflora (LELP), and suggests a depositional age between ca. 575 and 541 Ma. These are the first Precambrian acritarchs, reported so far, from northeastern Brazil. Their thermal alteration index (TAI) between $4+$ and 5, suggests metamorphic temperatures exceeding 200$250^{\circ} \mathrm{C}$. Even higher temperatures, recorded at the Angustura section, are probably related to contact metamorphism of the nearby Mucambo pluton. $\delta^{13} \mathrm{C}$ values of carbonates of $-3.5 \%$ VPDB at the base, passing up section into a positive plateau of up to $+3.7 \%$, and ${ }^{87} \mathrm{Sr} /{ }^{86} \mathrm{Sr}$ values between 0.7075 and 0.7080 (Chiglino 2013) are in broad agreement with a late Ediacaran age for the Frecheirinha Formation. Given the intruding Meruoca Granite that yielded an U-Pb SHRIMP age of $541 \pm 5 \mathrm{Ma}$ (Santos et al. 2013) and the reported occurrence of macrofossils of the Ediacara Fauna in the overlying Jaibaras Group (Barroso et al. 2014), the depositional age of the Frecheirinha Formation may be further constrained to between 575-555 Ma. A more comprehensive palynological study of the Frecheirinha Formation is necessary to confirm this age assignment. 


\section{ACKNOWLEDGMENTS}

We thank Gilsa M. Santana and Vilma S. Bezerra for their assistance with stable isotope analyses in the Laboratório de Isótopos Estaveis (LABISE). This study was partially supported by grants provided to ANS by Conselho Nacional de Desenvolvimento Científico e Tecnológico (CNPq); CNPq 470399/2008, CNPq 472842/2010-2, and Fundação de Amparo à Ciência e Tecnologia do Estado de Pernambuco (FACEPE) APQ 0727-1.07/08. The comments of anonymous reviewers helped improve an earlier version of the manuscript.

\section{RESUMO}

São descritos neste estudo, pela primeira vez, a ocorrêcia de microfósseis de parede orgânica e primeiros acritarcos do Nordeste do Brasil em calcáreos e margas Edicaranos da Formação Frecheirinha, Grupo Ubajara. A assembleia fóssil da Formação Frecheirinha representa uma microflora de baixa diversidade, englobando Leiosphaeridia, Lophosphaeridium e Bavlinella (=Sphaerocongregus) subordinada. $\mathrm{O}$ índice de alteração térmica (TAI) entre $4+$ e 5 , sugere temperaturas metamórficas superiores a $200-250^{\circ} \mathrm{C}$. Temperaturas mais altas provavelmente estão relacionadas à intrusão dos plútons graníticos (Meruoca, Mucambo). Valores negativos de $\delta^{13} \mathrm{C}$ de -3,5 \% VPDB (Vienna-Peedee Belemnite) nos carbonatos da base, um patamar de valores positivos de $+3,5 \%$ nos carbonatos da base, um patamar de valores positivos de $+3,5 \%$ nas seções do topo e os correspondentes valores de ${ }^{87} \mathrm{Sr} /{ }^{86} \mathrm{Sr}$ entre 0,7075 e 0,7080 foram reportados sugerindo idade Ediacarana. A assembleia de acritarcos é comparável a denominada Late Ediacaran Leiosphere Palynoflora (LELP) ou assembleia Kotlin-Rovno em concordância com os dados quimioestratigráficos. Macrofósseis pertencentes à Fauna Ediacara foram relatados no sobrejacente Grupo Jaibaras, que limitaria ainda mais a idade de deposição da Formação Frecheirinha entre ca, 575555 Ma. Estudos palinológicos mais abrangentes da
Formação Frecheirinha são necessários para confirmar a idade atribuída.

Palavras-chave: Acritarcos, Ediacarano, Neoproterozóico, nordeste do Brasil.

\section{REFERENCES}

BARRoSO FRG, VIANA MSS, LIMA FILHO MF AND AGOSTINHO SMO. 2014. First Ediacaran Fauna Occurrence in Northeastern Brazil (Jaibaras Basin, ?EdiacaranCambrian): Preliminary Results and Regional Correlation. An Acad Bras Cienc 86: 1029-1042.

BEURLEN K AND SOMMER FW. 1957. Observações estratigráficas e paleontológicas sôbre o calcário Corumbá. Bol Divisão Geol e Mineral/ DNPM 168: 1-47.

BlanCOG, RAJESHHM, GAUCHER C, GERMS GJBANDCHEMALE JR F. 2009. Provenance of the Arroyo del Soldado Group (Ediacaran to Cambrian, Uruguay): Implications for the paleogeographic evolution of southwestern Gondwana. Precambrian Res 171: 57-73.

Boggiani PC, GaUChER C, SiAL AN, BABINSKI M, SimON CM, RICCOMINI C, FERREIRA VP AND FAIRCHILD TR. 2010. Chemostratigraphy of the Tamengo Formation (Corumbá Group, Brazil): a contribution to the calibration of the Ediacaran carbon-isotope curve. Precambrian Res 182: 382-401.

BUTTERFIELD NJ AND CHANDLER FW. 1992. Palaeoenvironmental distribution of Proterozoic microfossils, with an example from the Agu Bay Formation, Baffin Island. Palaeontology 35: 943-957.

ButTerfield NJ, KNOLL AH AND SwetT K. 1994. Paleobiology of the Neoproterozoic Svanbergfjellet Formation, Spitsbergen. Fossils \& Strata 34: 1-84.

CABy R, Sial AN, ARTHAud M and VAuchez A. 1991. Crustal evolution and the Brasiliano orogeny, northeast Brazil. In Dallmeyer RD and Lécorché JP (Eds), The West African orogens and circum-Atlantic correlative, Springer-Verlag, p. 373-397.

CHIGLINO L. 2013. Quimiestratigrafía e Biostratigrafía da Formação Frecheirinha (Grupo Ubajara)-Nordeste do Brasil. PhD Thesis, Universidade Federal de Pernambuco, UFPE/BCTG 2013/320, p. 1-101.

Costa JM, DE Franç JB, CAVALCANTE Lins CA, BACCHIEGGA IF, HABeKost CR AND BARBosA DA CRUZ W. 1979. Geología da Bacia Jibaras Ceará, Piauí e Maranhão. Projeto Jaibaras. Ministério das Minas e Energías. DNPM. Série Geología Nº14, Seção Geología Básica Nº11, p. 106.

DOWNIE C. 1963. Hystrichospheres“ (acritarchs) and spores of the Wenlock Shales (Silurian) of Wenlock, England. Palaeontology 6(4): 625-652.

DOWNIE C AND SARJEANT WAS. 1963. On the interpretation of some hystrichosphere genera. Palaeontology 6: 83-96.

EISENACK A. 1958. Tasmanites Newton 1875 und Leiosphaeridia n.g. als Gattungen der Hystrichosphaeridia. Paleontographica, Abteilung A 110: 1-19. 
EVITT WR. 1963. A discussion and proposals concerning fossil dinoflagellates, hystrichospheres, and acritarchs, I. PNAS 49: 158-164.

FAIRCHILD TR, SANCHEZ EAM, PACHECO MLAF AND LEME JM. 2012. Evolution of Precambrian Life in the Brazilian Geologial Record. Intl J Astrobiology 11: 309-323.

FEDONKIn MA, SimonetTA A AND IVANTSOV AY. 2007. New data on Kimberella, the Vendian mollusc-like organism (White Sea region, Russia): palaeoecological and evolutionary implications. In: Vickers-Rich $\mathrm{P}$ and Komarower P (Eds), The Rise and Fall of the Ediacara Biota. Geol Soc London Spec Publ 286: 157-179.

FetTer AH, SANTOS TJS, VAN SCHMUS WR, HACKSPACHER PC, Brito NeVES BB, ARTHAUd MH, NOGUEIRA NETO JA AND WERNICK E. 2003. Evidence for neoproterozoic continental arc magmatism in the Santa Quitéria Batholith of Ceará State, NW Borborema Province, NE Brazil: implications for the assembly of West Gondwana. Gondwana Res 6: 265-273.

Frei R, Gaucher C, Døssing LN AND Sial AN. 2011. Chromium isotopes in carbonates a tracer for climate change and for reconstructing the redox state of ancient seawater. Earth Plan Sci Letters 236: 28-40.

Frei R, Gaucher C, Poulton SW AND CANFIELd DE. 2009. Fluctuations in Precambrian atmospheric oxygenation recorded by chromium isotopes. Nature 461: 250-254.

GAUCHER C. 2000. Sedimentology, palaeontology and stratigraphy of the Arroyo del Soldado Group (Vendian to Cambrian, Uruguay). Beringeria 26: 1-120.

Gaucher C, Blanco G, Chiglino L, Poiré DG and Germs GJB. 2008. Acritarchs of Las Ventanas Formation (Ediacaran, Uruguay): implications for the timing of coeval rifting and glacial events in western Gondwana. Gondwana Res 13: 488-501.

Gaucher C, Boggiani PC, SprechmanN P, Sial AN AND FAIRCHILD TR. 2003. Integrated correlationof the Vendian to Cambrian Arroyo del Soldado and Corumba Groups (Uruguay and Brazil) palaeogeographic, palaeoclimatic and palaeobiologic impli- cations. Precambrian Res 120: 241-278.

Gaucher C, Chiglino L AND PeCoIts E. 2004b. Southernmost exposures of the Arroyo del Soldado Group (Vendian to Cambrian, Uruguay): palaeogeographic implications for the amalgamation of W-Gondwana. Gondwana Res 7(3): 701-714.

GAUCHER C, FrIMMEL HE AND GERMS GJB. 2005a. Organicwalled microfossils and biostratigraphy of the upper Port Nolloth Group (Namibia): implications for the latest Neoproterozoic glaciations. Geol Mag 142(5): 1-21.

GAUCHER C AND GERMS GJB. 2006. Recent advances in South African Neoproterozoic-Early Palaeozoic biostratigraphy: correlation of the Cango Caves and Gamtoos Groups, and acritarchs of the Sardinia Bay Formation, Saldania Belt. S Afr J Geol 109: 193-214.

GAUCHER CAND POIRÉ D. 2009. Biostratigraphy. NeoproterozoicCambrian evolution of the Río de la Plata Palaeocontinent. In: Gaucher C, Sial AN, Halverson GP and Frimmel HE (Eds), Neoproterozoic-Cambrian tectonics, global change and evolution: a focus on southwestern Gondwana. Developments in Precambrian Geol, 16, Elsevier, p. 103-114.
Gaucher C, Poiré DG, Gómez Peral L And Chiglino L. 2005b. Litoestratigrafía, bioestratigrafía y correlaciones de las sucesiones sedimentarias del NeoproterozoicoCámbrico del Cratón del Rio de la Plata (Uruguay y Argentina). Latin Am J of Sediment and Basin Anal 12: 145-160.

Gaucher C, Sial AN, Blanco G and Sprechmann P. 2004a. Chemostratigraphy of the lower Arroyo del Soldado Group (Vendian, Uruguay) and paleoclimatic implications. Gondwana Res 7: 715-730.

Gaucher C, Sial AN, Poiré D, Gómez-Peral L, Ferreira VP AND PIMENTEL MM. 2009. Chemostratigraphy. Neoproterozoic-Cambrian evolution of the Río de la Plata Palaeocontinent. In: Gaucher C, Sial AN, Halverson GP and Frimmel HE (Eds), Neoproterozoic-Cambrian tectonics, global change and evolution: a focus on southwestern Gondwana. Developments in Precambrian Geol, 16, Elsevier, p. 115-122.

GAUCHER C AND SPRECHMANN P. 2009. Neoproterozoic acritarch evolution. Neoproterozoic-Cambrian biota. In: Gaucher C, Sial AN, Halverson GP and Frimmel HE (Eds), Neoproterozoic-Cambrian tectonics, global change and evolution: a focus on southwestern Gondwana. Developments in Precambrian Geol, 16, Elsevier, p. 319-326.

Gaucher C, Sprechmann P And Montaña J. 1998. New advances on the geology and paleontology of the Vendian to Cambrian Arroyo del Soldado Group of the Nico Pérez Terrane of Uruguay. $\mathrm{N} \mathrm{Jb}$ für Geol und Paläont, Mh 1998(2): 106-118.

German TN, MikHAJlova NS AND YANKAUSKAS TV. 1989. Sistematicheskoe opisanie mikrofossilij [Systematic description of microfossils]. In: Yankauskas TV (Ed), Mikrofossilii Dokembriya SSSR [Precambrian microfossils of the USSR], Leningrad, Nauka, p. 34-151.

Germs GJB, KNOLL AHAND VidAl G. 1986. Latest Proterozoic microfossils from the Nama Group, Namibia (South West Africa). Precambrian Res 32: 45-62.

Germs GJB, Miller R McG, Frimmel HE AND GAUCher C. 2009. Syn- to late-orogenic sedimentary basins of southwestern Africa. Neoproterozoic to Early Palaeozoic evolution of southwestern Africa. In: Gaucher C, Sial AN, Halverson GP and Frimmel HE (Eds), NeoproterozoicCambrian tectonics, global change and evolution: a focus on southwestern Gondwana. Developments in Precambrian Geol, 16, Elsevier, p. 183-203.

GREY K. 2005. Ediacaran palynology of Australia. Memoir Association of Australasian Palaeontologists 31: 1-439.

GREY K, WALTER MR AND CALVER CR. 2003. Neoproterozoic biotic diversification: Snowball Earth or aftermath of the Acraman impact. Geology 31: 459-462.

Grotzinger JP, Bowring SA, SAYLOR BZ AND KAUfMAN AJ. 1995. Biostratigraphic and Geochronologic Constraints on Early Animal Evolution. Science 270: 598-604.

HACKSPACHER PC, SoARES JS AND PETTA RA. 1988. Geologia do Grupo Ubajara, região de Frecheirinha (CE). In: Congr. Bras. Geol., 35. Anais, Belém, 1988, SBG 6: 2661-2677. 
HALVERSON GP, DudÁS FÖ, MALOOF A AND BOWRING SA. 2007. Evolution of the ${ }^{87} \mathrm{Sr} /{ }^{86} \mathrm{Sr}$ composition of Neoproterozoic seawater. Palaeogeogr, Palaeoclimatol, Palaeoecol 256: 103-129.

Halverson GP, HofFman PF, Schrag DP, Maloof AC AND RICE AHN. 2005. Towards a Neoproterozoic composite carbon isotope record. Geol Soc Am Bull 117: 1181-1207.

HALVERSON GP, WADE BP, HURTENG MT AND BAROVICH KM. 2010. Neoproterozoic chemostratigraphy. Precambrian Res 182: 337-350.

HOFFMAN PF, HAWKINS DP, ISACHSEN CE AND BOWRING SA. 1996. Precise U-Pb zircon ages for early Damaran magmatism in the Summas Mountains and Welwitschia inlier, northern Damara belt, Namibia. Commun Geol Survey Namibia 11: 47-52.

HOFFMAN PF AND SCHRAG DP. 2002. The snowball Earth hypothesis: testing the limits of global change. Terra Nova 14: 129-155.

HOFFMANN KH, CONDON DJ, BOWRING SA AND CROWLEY JL. 2004. A U-Pb zircon date from the Neoproterozoic Ghaub Formation, Namibia: constraints on Marinoan glaciation. Geology 32: 817-820.

HoFMANN HJ AND JACKSON GD. 1996. Notes on the geology and micropaleontology of the Proterozoic Thule Group, Ellesmere Island, Canada, and north-west Greenland. Geol. Survey of Canada, Bull 495: 1-26.

Huntley JW, XiaO S AND KoWALEWSKI M. 2006. 1.3 billion years of acritarch history: an empirical morphospace approach. Precambrian Res 144: 52-68.

Jacobsen SB And Kaufman AJ. 1999. The Sr, C and O isotopic evolution of Neoproterozoic seawater. Chem Geol 161: 37-57.

JANKAUSKAS TV, MiKhaILOVA NS AND HERMANN TN 1989. Mikrofossilii Dokembriya SSSR. [Precambrian Microfossils of the USSR] Nauka, Leningrad.

Karlstrom KE ET AL. 2000. Chuar Group of the Grand Canyon: Record of breakup of Rodinia, associated change in the global carbon cycle, and ecosystem expansion by 740 Ma. Geology 28: 619-622.

KAUFMAN AJ AND KNOLL AH. 1995. Neoproterozoic variations in the C-isotopic composition of seawater. Precambrian Res 73: 27-49.

Kendall BS, Creaser RA and Selby D. 2006. Re-Os geochronology of postglacial black shales in Australia: constraints on the timing of "Sturtian" glaciation. Geology 34: 729-732.

KNOLL AH, BLICK N AND AwRAMIK SM. 1981. Stratigraphic and ecologic implications of late Precambrian microfossils from Utah. Am J Sci 281: 247-263.

LINK PK AND CHRISTIE-BLICK N. 2011. Neoproterozoic strata of southeastern Idaho and Utah: record of Cryogenian rifting and glaciation: In: Arnaud E, Halverson GP and Shields-Zhou G (Eds), The Geological Record of Neoproterozoic Glaciations. Geol Soc London Mem 36: 425-436.
LiU P, Yin C, Chen S, Tang F and GaO L. 2013. The biostratigraphic succession of acanthomorphic acritarchs of the Ediacaran Doushantuo Formation in the Yangtze Gorges area, South China and its biostratigraphic correlation with Australia. Precambrian Res 225: 29-43.

LISTER TR. 1970. The acritarchs and chitinozoa from the Wenlock and Ludlow Series of the Ludlow and Millichope areas, Shropshire. Palaeontographical Soc Monograph 124: $1-100$.

Mallmann G, Chemale F, Avila JN, Kawashita K and ARMSTRONG RA. 2007. Isotope geochemistry and geochronology of the Nico Pérez Terrane, Río de la Plata Craton, Uruguay. Gondwana Res 12: 489-508.

MELEZHIK VA, GoROKOV IM, KuZNESTOV AB AND FALlick AE. 2001. Chemostratigraphy of Neoporterozoic carbonates: implication for "blind dating. Terra Nova 13: 1-11.

MocZYDŁOWSKA M. 2008. The Ediacaran microbiota and the survival of Snowball Earth conditions. Precambrian Res 167: 1-15.

MoczydŁowsKa M AND Konstantin EN. 2012. Ediacaran radiation of organic-walled microbiota recorded in the Ura Formation, Patom Uplift, East Siberia. Precambrian Res 198-199: 1-24.

Moorman M. 1974. Microbiota of the late Proterozoic Hector Formation, southwestern Alberta, Canada. J Paleontol 48: 524-539.

NAGY RM AND PORTER SM. 2005. Paleontology of the Neoproterozoic Uinta Mountain Group. In: Dehler CM, Pederson JL, Sprinkel DA and Kowallis BJ (Eds), Uinta Mountain geology. Utah Geol Assoc Publ 33: 49-62.

NAGy RM, Porter SM, DeHLER CM AND SHEN Y. 2009. Biotic turnover driven by eutrophication before the Sturtian low latitude glaciation. Nature Geosci 2: 415-418.

NARBONNE GM. 2005. The Ediacara Biota : Neoproterozoic Origin of Animals and Their Ecosystems. Annu Rev Earth Planet Sci 33: 421-442.

NAUMOVA SN. 1949. Spory nizhnego kambriya. Izsvestiya Akademiya Nauk SSSR, Seriya Geologicheskaya, p. 49-56.

OLIVEIRA DC. 2000. Revaluation of the tectono-magmatic evolution of the Jaibaras Trough (northeast Brazil). Acta Geol Hispanica 36: 53-95.

OyhantÇabal PB, Siegesmund S, WEMMER K, PRESNyakov S AND LAYER P. 2009. Geochronological constraints on the evolution of the southern Dom Feliciano Belt (Uruguay). J Geol Soc London 166: 1075-1084.

Pflug HD AND Reitz E. 1992. Palynostratigraphy in Phanerozoic and Precambrian Metamorphic Rocks. In: Schidlowski M, Golubic S, Kimberley MM, McKirdy DM and Trudinger PA(Eds), Early Organic Evolution: Implications for Mineral and Energy Resources, Springer, Berlin, p. 509-518.

SAntos RV, Oliveira CGD, PARENTE CV, Garcia MDGM AND DANTAS EL. 2013. Hydrothermal alteration related to a deep mantle source controlled by a Cambrian intracontinental strike-slip fault: Evidence for the Meruoca felsic intrusion associated with the Transbraziliano Lineament, northeastern Brazil. J S Am Earth Sci 43: 33-41. 
SANTOS STJ, FETTER AH, HACKSPACHER PC, VAN SCHUMS WR AND NOGUEIRA NeTO JA. 2008. Neoproterozoic tectonic and magmatic episodes in the NW sector of Borborema Province, NE Brazil, during assembly of Western Gondwana. J S Am Earth Sci 25: 271-284.

SCHOPF JW, 1992. Atlas of representative Proterozoic microfossils. In: Schopf JW and Klein C (Eds), The Proterozoic Biosphere-A Multidisciplinary Study. Cambridge University Press, Cambridge, p. 1054-1117.

SergeEV VN, KNOLl AH AND VorobeVA NG. 2011. Ediacaran microfossils from the Ura Formation, BaikalPatom Uplift, Siberia: taxonomy and biostratigraphic significance. J Paleont 85: 987-1011.

SIAL AN. 1989. Petrologia, geoquímica de elementos maiores, traços, terras raras e isótopos $(\mathrm{Sr}, \mathrm{O}, \mathrm{H}, \mathrm{S})$ nos batólitos da Meruoca e Mocambo, Ceará, Nordeste do Brasil. Tese de Titular, Universidade Federal de Pernambuco, Recife, 284 p.

SiAl AN, Ferreira VP, ALMEIDA AR AND MoURA CVA. 2003. $\mathrm{C}$-, $\mathrm{O}$ - and $\mathrm{Sr}$ isotope composition and age of the carbonates of the Frecheirinha Formation, NW Ceará, Northeastern Brazil. IX Congresso Brasileiro de Geoquímica. BelémPará. Resumos Expandidos, p. 410-411.

Sial AN, Ferreira VP, Almeida AR, Romano AW, PARENTE CV, Costa ML and SAntos VH. 2000. Carbon isotope fluctuations in Precambrian carbonate sequences of several localities in Brazil. An Acad Bras Cienc 72: 539-558.

SiAL AN AND LONG LE. 1987. Mineral chemistry and stable isotope geochemistry of the Cambrian Meruoca and Mucambo plutons, Ceará, Northeast Brazil. International Symposium on Granites and Associated Mineralizations (ISGAM), Salvador, Brazil, p. 185-188.

STANIER RY ET AL. 1978. Proposal to place nomenclature of the Cyanobacteria (blue-green algae) under the rules of the International Code of Nomenclature of Bacteria. Intl J System Bacteriology 28: 335-336.

TEICHMÜLLER M, LITTKE R AND ROBERT P. 1998. Coalification and maturation. In: Taylor GH, Teichmüller M, Davis A, Diessel CFK, Littke R and Robert P (Eds), Organic Petrology, Gebrüder Borntraeger, Berlin, p. 86-174.

Timofeev BV. 1959. Drevnejshaya flora Pribaltiki. Trudy VNIGRI 129, Leningrad, 320 p.

TIMOFEEV BV. 1966. Micropaleophytological Investigations of Ancient Formalions, Academy of Sciences USSR, 147 p. [In Rusian].
TURNER RE 1984. Acritarchs from the type area of the Ordovician Caradoc Series, Shropshire, England. Palaeontographica B 190: 87-157.

VIDAL G. 1976. Late Precambrian microfossils from the Visingsö Beds in southern Sweden. Fossils \& Strata 9: 1-57.

VIDAL G AND MOCZYDLOWSKA-VIDAL M. 1997. Biodiversity, speciation, and extinction trends of Proterozoic and Cambrian phytoplankton. Paleobiol 23: 230-246.

WALTer MR, Veevers JJ, CALVER CR, GorJan P AND HILl AC. 2000. Dating the 840-544 Ma Neoproterozoic interval by isotopes of strontium, carbon and sulphur in seawater and some interpretative models. Precambrian Res 100: 371-433.

WARREN LV, PACHECO MLAF, FAIRChILd TR, SimÕES MG, RicCOMINI C, BOGGIANI PC AND CÁCERES AA. 2012. The dawn of animal skeletogenesis: Ultrastructural analysis of the Ediacaran metazoan Corumbella werneri. Geology 40: 691-694.

Willman S, MoczydlowsKa M AND GREY K. 2006. Neoproterozoic (Ediacaran) diversification of acritarchs a new record from the Murnaroo 1 drillcore, eastern Officer Basin, Australia. Review Palaeobot Palynol 139: 17-39.

WoESE CR AND Fox GE. 1977. Phylogenetic structure of the prokaryotic domain: the primary kingdoms. PNAS 74: 5088-5090.

YIN L AND YUAN X. 2007. Radiation of Meso-Neoproterozoic and early Cambrian protists inferred from the microfossil record of China Palaeogeog, Palaeoclimatol, Palaeoecol 254: 350-361.

ZAINE MF AND FAIRCHILD TR. 1985. Comparison of Aulophycus lucianoi Beurlen \& Sommer from Ladário (MS) and the genus Cloudina Germs, Ediacaran of Namibia. An Acad Bras Cienc 57: 130.

ZANG WL AND WALTER MR. 1992. Late Proterozoic and Early Cambrian microfossils and biostratigraphy, Amadeus Basin, central Australia. Mem Assoc Australasian Palaeontol 12: 1-132.

ZHANG S, JiANG G AND HAN Y. 2008. The age of the Nantuo Formation and Nantuo glaciation in South China. Terra Nova 20: 289-294. 
